\title{
THE EDICT OF DIOCLETIAN FIXING MAXIMUM PRICES
}

In the year 284 A. D., Diocletian (as we now know the Dalmatian soldier of lowly origin) was by his soldiers proclaimed Augustus or Emperor of the Roman Empire, stretching from the Atlantic Ocean to Mesopotamia. This vast expanse he soon found to be too great for his sole administration, and he appointed an associate Augustus in 286 and two Caesars or assistants in 293. In this action he had precedent, but he made more definite the governmental division, each of the four having his own quarter of the Empire with his own capital and his own army.

In these and the following years the prices of commodities of all sorts and the wages of laborers reached unprecedented heights. In the year 30I, consequently, Diocletian felt obliged to issue an Edict fixing maximum prices for practically all articles and services. Of this Edict we know but little from literary sources'; but as it was published in inscriptional form throughout the countries to which it applied, we have the actual text recorded in stone. The preamble we possess practically entire, in four incomplete copies which mutually complete one another. The most nearly complete copy is also that which has been longest known; it was found and copied at Stratonicea (now Eski-Hissar) in that part of Asia Minor anciently called Caria, by a Mr. Sherard, who was English consul at Smyra from I702 to I7I8. The next in importance is a copy which was brought from somewhere in Egypt to Aix in Southern

1 Three passages at most. There is an important passage in the De Mortibus Persecutorum, which passes under the name of Lactantius, but is of doubtful authorship; this will be discussed later in the text. The Fasti Idatiani (printed in Migne, Patrologia Latina, vol. 5I, pp. $89 \mathrm{I} \mathrm{ff}$.), a list of consuls with an occasional historical note, remarks to the year 302 A. D.: "his cos. vilitatem iusserunt imperatores esse"- "when these were consuls the emperors ordered a cheapness of goods to exist"; it has been proven conclusively by the date in the edict itself that this date is one year too late. It is just possible that there is an allusion to these events in Aurelius Victor, de Caesaribus, 39, 45, "annone urbis ac stipendiorum salus anxie solliciteque habita"- "the price of grain in the city and the safety of the taxes were a matter of anxiety and worry." 
France, where it has been since 1807. Third, there is the almost equally considerable portion found in 1889 at Plataea in Greece by Professor Rolfe, of the University of Pennsylvania, and Sir Charles Waldstein, of Cambridge University and now in the Museum in Athens. Fourth, there is a small fragment found at Gythium in Southern Greece in 1892. Since that time, three more fragments of the preamble, all of insignificant length, have been found in different places. As for the price-lists, we have portions found in about thirty places, showing that the edict had at least thirty-two schedules and well over one thousand items; it happens that most of the price-lists are not in Latin, but in Greek, because they have been found in the Greekspeaking lands of the Empire: Greece, Asia Minor, and Egypt. Curiously, we have no fragments of the preamble in Greek. ${ }^{2}$

The materials for determining the cause of the high prices are very scanty. In the seventh chapter of the $D e$ Moribus Persecutorum, of uncertain authorship, but written in Asia Minor not long after the time of the Edict, the writer lays all the blame on the outrageous misrule of Diocletian; he had appointed three associates, each of whom had a court and larger armies than previously had existed in the whole empire; there was an enormous increase of officialdom; taxes for their support became so high that it was no longer profitable to till the fields, which were left idle and allowed to return to woodland; the continual requisitions for the use of officials and armies bore heavily on the people; yet the imperial treasuries were never allowed to

2 The most important publications of this Edict are the following (apart from some older editions now of minor significance):

Th. Mommsen, Berichte der sächsischen Gesellschaft der Wissenschaften, plilologisch-historische Klasse, III ( $185 \mathrm{I}$ ), pp. I-80; W. H. Waddington, Edit de Diocletien etablissant le maximum dans l'empire romain (1864), a reprint of the text, with commentary, from his edition of the late Ph. LeBas's Inscriptions grecques et latines; Th. Mommsen, Corpus Inscriptionum Latinarum, III (I873), pp. 80I-841; III Suppl. (1892), 1909-53., J. C. Rolfe and F. B. Tarbell, A New Fragment of the Preamble to Diocletzan's Edict, "De Pretiis Rertim Venalizm," in Papers of the American School of Classical Studies at Athens, V (1892), pp. 233-244. Th. Mommsen and Hugo Blümner, Der Maximaltarif des Diocletian (1893). 
become empty, for the emperors hoarded up a portion of the revenues which came in; there was tremendous building activity, especially at Nicomedia, Diocletian's capital; when a building was completed, the emperor declared his dissatisfaction and ordered it rebuilt, often by forced labor of the people, so that men fled from the places where building was going on; men of wealth were condemned to death under trumped-up charges, that their properties might be confiscated into the imperial treasury.

But this formidable arraignment of Diocletian can hardly stand in all particulars. The writer was a Christian, embittered at the government which persecuted his coreligionists, and hardly in an impartial frame of mind. The Emperor himself, in the preamble to the Edict, ascribes the rise of prices entirely to the greed of the merchants, many of whom seem by his description to be similar to the modern profiteers, for they hoped that the weather would not favor good crops and they tried to control the seedsupply. He had long hoped, he says, that prices would presently settle down to their natural level, without any governmental interference, but since this hope had proved futile, he must interfere for the welfare of his subjects. What seemed to pain him most was that prices were raised to their highest pitch when soldiers were the purchasers.

Diocletian's picture of the circumstances is perhaps quite as one-sided as that of the Christian writer. Our knowledge of the history of the times enables us to get a fairly clear picture of the circumstances which led to the increase in prices, and shows factors mentioned by neither. In the first place, before the accession of Diocletian to imperial power, there had been a long succession of short-time rulers, elevated by their soldiers, and maintained by force, most of them of little ability. Aurelian alone stood out above the rest in the half century before Diocletian. Such civil warfare and uncertainty in the government is extremely expensive, since it consumes or destroys accumulated wealth and in addition hampers or renders impossible the produc- 
tion and distribution of goods and commodities. Diocletian, as we have seen, attempted at his accession to better the administrative conditions by appointing co-rulers, with whom he divided the Empire; but this, as his Christian critic says, greatly increased the taxes, for there was now not merely a single imperial court to be maintained, but four courts, each with its attendant officials and its armies. The enlarged armies were, it is true, necessitated by the assaults of barbarian tribes on the frontiers of the Rhine, the Danube, in Mesopotamia and elsewhere, but that did not make the payment of additional taxes easier. An additional source of expense was entailed by having four capital cities, one for each ruler. Suitable governmental buildings had to be constructed in each city, and Diocletian at Nicomedia in northwestern Asia Minor was in fact a great builder. Under this heavy taxation, there was a great increase in slavery, and the liberties even of the free towns were restricted or lost. And the results of such taxation made increasingly difficult the raising of the taxes. The product was a vicious circle, not only of difficulty in securing the taxes, but of increase in the cost of articles of trade. Yet Diocletian must not be looked upon as the wilful cause of the distress, for in most respects the division of authority and the partitioning of the Empire was well-advised, and tended toward stability and personal safety. But the Empire was reaping the fruits of the preceding years of civil warfare and misrule, and was in no condition to bear the expense necessarily attending administrative reform.

There was another important cause of the increase in prices, which has been intentionally left until the last, namely the debasing of the coinage. In the late Republic and early Empire, the standard coin was the silver denarius, the ancestor of the franc, and worth approximately the same as that coin. ${ }^{3}$ But from time to time the amount of . silver in the coin had been reduced, until shortly before price.

- That is the franc at its normal value, and not at its present depreciated 
Diocletian the emperors were issuing tin-plated copper coins under the old name. Silver and gold coinage naturally disappeared from circulation. Diocletian took the bull by the horns and issued a new denarius which was frankly of copper, and made no pretense of being anything else; in doing this he established a new standard of value. The effect of this upon prices needs no explanation; there was a readjustment upward, and very much upward. The establishment of a uniform coinage should have tended to stabilize prices at a new level; but apparently the new level was too high to please the Emperor, for, as we have said, in $30 \mathrm{r}$ he issued an Edict fixing maximum prices.

Before passing to the text of the Edict, we might consider briefly its working; the available material, in fact, permits only a brief treatment. The writer De Mortibus Persecutorum, in the seventh chapter, says, "He (Diocletian) likewise, when by his varied unreasonable tax-levies he caused an immeasurable rise in prices, tried to regulate the prices of merchandise. Then much blood was shed over trifling and cheap articles; through fear, wares were withheld from market, and the rise in prices became much worse, until after the death of many men the law was through very necessity rescinded." 4 In other words, the price limits set in the Edict were not observed by the traders, in spite of the death penalty provided in the statute for its violation; would-be purchasers, finding that the prices were above the legal limit, formed mobs and wrecked the offending traders' establishments, incidentally killing the traders, though the goods were after all of but trifling value; ${ }^{5}$ the other traders, rather than sell at prices which would bank-

The text of this important passage is as follows: "Idem (Diocletianus) cum variis iniquitatibus immensam faceret caritatem, legem pretiis rerum venalium statuere conatus est. Tunc ob exigua et vilia mulius sanguis effușus, nec venale guicquam melu apparebat et caritas multo deterius exarsit, donec lex necessitate ipsa post multorum exitum solveretur."

"Such seems to be the most natural interpretation of "tunc ob exigua et vilia multus sanguis effusus," but two other meanings are possible: (I) That many dealers, even in wares of low value, were executed in accord with the provisions of the law for its infraction; or (2) that the tradesmen forcibly resisted, even to the point of bloodshed and loss of life, the attempt of the government officials to enforce the price limits. 
rupt them, hoarded their goods against the day when the restrictions should be removed, and the resulting scarcity of wares actually offered for sale caused an even greater increase in prices, so that what trading went on was at illegal prices, and therefore performed clandestinely.

Ultimately the Edict was of necessity rescinded; how long it remained in force is unknown. But Diocletian is known to have abdicated the imperial power in 305 , four years after the promulgation of the Edict; the cause assigned was ill-health resulting from the strain and burden of government. It would not be going very far from likelihood to assume that the failure of the Edict to restore business stability was a considerable factor in his poor health and abdication, and that the Edict was rescinded very soon after his abdication, if not indeed before. It remained law, therefore, not much if at all over four years.

As to the text of the Edict, it is headed by the full names and titles of Diocletian and his co-Augustus and his two Caesars, and is therefore issued in the names of all four. This gives the impression that it was meant to apply to the whole Empire, but the thirty-five copies of which greater or smaller portions have been found, all come from Greece, Asia Minor, and Egypt, which lay in Diocletian's special quarter, and the writer of De Mortibus Persecutorum ascribes the Edict to Diocletian alone. Further the articles of local use or manufacture, which are listed in the schedules, all are of this same region. The natural conclusion is that it was intended only for the section which was under the especial administration of Diocletian.

The preamble is of some length, and is couched in language which is as difficult, obscure, and verbose as anything composed in Latin. Diocletian doubtless wished to express his subjects by the terrifying complexity of the involved sentences; and it is tempting to surmise that he secured a mixed committee of lawyers and grammarians to draw it up. One scholar pronounces it "à peine intelligible dans certains passages," and another speaks of it as being com- 
posed "in schwer verstandlicher, theils gespreitzer, theils schwülstiger Sprache." In French and in German there exist, apparently, no translations, but only some muchabridged summaries; in English there is a translation by Professor Rolfe, of the University of Pennsylvania, and Professor Tarbell, of the University of Chicago, presented with much hesitancy on their part, and running only to the middle of the eleventh sentence, where the Plataean fragment which they were editing comes to an end. In presenting herewith a complete translation of the preamble, therefore, the author is moved by the desirability of having it accessible to students in an English form, and he is not unaware of his own temerity in attempting the task; but he is reassured by the kindness of Professor Rolfe, who has consented to the use of his and Tarbell's translation, so far as it goes, with such verbal changes as the present writer cares to make. The following, then, is the text of this remarkable document, arranged for convenience in paragraphs of one sentence each:

"I. The national honor and the dignity and majesty of Rome demand that the fortune of our State-to which, next to the immortal gods, we may, in memory of the wars which we have successfully waged, return thanks for the tranquil and profoundly quiet condition of the world-be also faithfully administered and duly endowed with the blessings of that peace for which we have laboriously striven; to the end that we, who under the gracious favor of the gods have repressed the furious depredations, in the past, of barbarous tribes by the destructions of those nations themselves, may for all time gird with the bulwarks due to justice the peace which has been established.

"2. To be sure, if any spirit of self-restraint were holding in check those practices by which the raging and boundless avarice is inflamed, an avarice which, without regard for the human race, not yearly or monthly or daily only, but almost every hour and even every moment, hastens toward its own development and increase; or if the common fortunes could with calmness bear this orgy of license, by which, under their unhappy star, they are from day to day ripped to pieces-peradventure there would seem to be room left for shutting our eyes and holding our peace, since the united endurance of men's minds would ameliorate this detestable enormity and pitiable condition.

" 3 . But since it is the sole desire of untamed fury to feel no love for the ties of our common humanity; and since among the 
wicked and lawless it is held to be, so to speak, the religious duty of an avarice that swells and grows with fierce flames, that, in harrying the fortunes of all, it should desist of necessity rather than voluntarily; and since those whom extreme poverty has brought to a perception of their most wretched condition cannot further keep their eyes shut; it suits us, who are the watchful parents of the whole human race, that justice step in as an arbiter in the case, in order that the long-hoped-for result, which humanity could not achieve by itself, may, by the remedies which our forethought suggests, be contributed toward the general alleviation of all.

"4. And of this matter, it is true, as the common knowledge of all recognizes and indisputable facts proclaim, the consideration is almost too late, since we form plans or delay discovered remedies in the hope that, as was to be expected from natural justice, humanity, detected in most odious crimes, might work out its own reformation; for we thought it far better that the censure of intolerable robbery should be removed from the court of public opinion by the feeling and decision of those men themselves, who rush daily from bad to worse and in a sort of blindness of mind tend toward outrages upon society, and whom their grave misdoing has branded as enemies alike to individuals and to the community, and guilty of the most atrocious inhumanity.

" 5 . Therefore we proceed promptly to apply the remedies long demanded by the necessity of the case, and that too, feeling no concern about complaints that our corrective interference may, as coming unseasonably or unnecessarily, be considered cheaper or less valuable even in the eyes of the wicked, who, though seeing in our silence of so many years a lesson in self-restraint, nevertheless refused to follow it.

" 6 . For who has so dull a breast, or is so alien to the feeling of humanity, that he can be ignorant, nay rather has not actually observed that in commodities which are bought and sold in markets or handled in the daily trade of cities, the wantonness in prices had progressed to such a point that the unbridled greed for plundering might be moderated neither by abundant supplies nor by fruitful seasons?

"7. So that there is clearly no doubt that men of this sort, whom these occupations have engaged, are always mentally calculating and even seeking, from the motions of the stars, to take advantage of the very winds and seasons, and by reason of their wickedness cannot bear that the fields be watered and made productive by the rains of heaven, so as to give hope of future crops, since they consider it a personal loss for abundance to come to the world by the favorable moods of the sky itself.

"8. And to the avarice of those who are always eager to turn to their own profit even the blessings of the gods, and to check the tide of general prosperity, and again in an unproductive year to 
haggle about the sowing of the seed and the business of retail dealers; who, individually possessed of immense fortunes which might have enriched whole peoples to their heart's content, seek private gain and are bent upon ruinous percentages of profitto their avarice, ye men of our provinces, regard for common humanity impels us to set a limit.

"9. But now, further, we must set forth the reasons themselves, whose urgency has at last compelled us to discard our too long protracted patience, in order that-although an avarice which runs riot through the whole world can with difficulty be laid bare by a specific proof, or rather fact-none the less the nature of our remedy may be known to be more just, when utterly lawless men shall be forced to recognize, under a definite name and description, the unbridled lusts of their minds.

"Io. Who therefore can be ignorant that an audacity that plots against the good of society is presenting itself with a spirit of profiteering, wherever the general welfare requires our armies to be directed, not only in villages and towns, but along every highway? That it forces up the prices of commodities not fourfold or eightfold, but to such a degree that human language cannot find words to set a proper evaluation upon their action? Finally, that sometimes by the outlay upon a single article the soldier is robbed both of his bounty and of his pay, and that the entire contributions of the whole world for maintaining the armies accrue to the detestable gains of plunderers, so that our soldiers seem to yield the entire fruit of their military career, and the labors of their entire term of service, to these profiteers in everything, in order that the pillagers of the commonwealth may from day to day carry off all that they resolve to have?

"II. Being justly and duly moved by all these considerations above included, since already humanity itself seemed to be praying for release, we resolved, not that the prices of commodities should be fixed-for it is not thought just that this be done, since sometimes very many provinces exult in the good fortune of the low prices which they desire, and as it were in a certain privileged state of abundance-but that a maximum be fixed; in order that, when any stress of high prices made its appearance-which omen we prayed the gods might avert-avarice, which could not be checked on the so-to-speak endlessly extending plains, might be confined by the bounds of our statute and the limits set in the law promulgated to control them.

"I2: It is our pleasure, therefore, that those prices, which the concise items of the following list indicate, be held in attention throughout our whole domain, in such a way that all men understand that freedom to exceed them is removed; while at the same time, in those places where goods manifestly abound, the happy condition of cheap prices shall not thereby be hampered-and ample provision is made for cheapness, if avarice is limited and curbed. 
"13. Between sellers, moreover, and buyers whose custom it is to enter trading-ports and visit provinces overseas, this restraint will have to be a mutual action, that, while they already of themselves know that in the need imposed by high prices the price-limits cannot be exceeded, at the time of retailing such a reckoning of places and bargainings and of the whole transaction be figured out, that under it there is manifestly a fair agreement that those who transport the goods shall nowhere sell at an unduly high price.

"I4. Because, therefore, it is an established fact that among our ancestors also the methods employed in new enactments was that boldness be curbed by a prescribed penalty-since very rarely is a status found for men which will benefit them with their free consent, but it is always fear, justest teacher of duties, which will restrain and guide them in the right path-it is our pleasure that if anyone have acted with boldness against the letter of this statute, he shall be subjected to capital punishment.

"I5. And let none think that a hard penalty is set, though when the time comes the observance of moderation will be a refuge for averting the peril.

"I6. He also shall be subject to the same peril, who in eagerness to purchase has come to an agreement with an avarice which retails in violation of the statutes.

"I7. From such guilt also he too shall not be considered free, who, having goods necessary for food or usage, shall after this regulation have thought that they might be withdrawn from the market; since the penalty ought to be even heavier for him who causes need than for him who makes use of it contrary to the statutes.

"I8. We therefore appeal to the devotion of all, that the decision made for the public welfare be observed with generous obedience and due scrupulousness, especially since by such a statute provision is manifestly made not only for the individual states and peoples and provinces, but for the whole world, for whose ruin a few, we learn, have raged exceedingly, whose greed neither length of time nor the riches which they are seen to have desired, have been able to moderate or satisfy."

The provisions of the Edict are, in simple language, that maximum prices are set for articles of trade and for services, and that these are not to operate in such a way as to raise prices where the current level of prices is lower; that traders shall not buy in localities where prices are low and transport and sell the goods elsewhere at the maximum price; that the penalty for the violation of the law is death, and that leniency is not to be expected in return 
for a conciliatory attitude in court; further, that the same penalty applies to him who purchases at an illegally high price, and to him who hoards goods and refuses to put them on the market at legal price.

After the preamble come the price lists arranged in schedules. The prices are fixed in the denarius, no longer a silver coin but one of copper, the value of which at the time of Diocletian was established by the discovery of a fragment of the Edict, in which the price of one Roman pound of refined gold was set at 50,000 denarii; the copper denarius was therefore worth .434 cents. Many of the items in the schedules are for commodities no longer current, and others are preserved in so fragmentary a state that the prices cannot be read. A few of the more interesting items of the various schedules are given below, with the weights, measures and prices changed into United States standards of the present day. ${ }^{6}$

Barley

Rye, or Oats ${ }^{7}$

Dried beans

Old wine

Beer

Olive oil, best quality

Vinegar

Salt

$\begin{array}{cc}\text { per bushel } & \$ .873 \\ \text {." } & .524 \\ \text { “ quart } & .054 \\ \text {." “ } & .181 \\ \text { “ “ } & .03 \\ \text { "“ “ } & .30 \\ \text { " bushel } & .045 \\ & .873\end{array}$

6 Weights were measured in the pondo or libra, the pound, which was equal to $.722 \mathrm{lbs}$. avoirdupois and to $.875 \mathrm{lbs}$. troy; and in the uncia, the ounce, which was one-twelfth of the Roman pound, or $.963 \mathrm{oz}$. avoirdupois and $.875 \mathrm{oz}$. troy. Lengths were measures by the cubitus, the ell, or 17.46 inches; and by the digilus, the finger, one twenty-fourth of the ell, or .73 inches.

Dry commodities sold in bulk were measured by the Italicus modius, the Italian peck, which equaled 7.95 dry quarts, or almost precisely one peck; the caslrensis modius, the military peck, had double the capacity of the Italian peck. The Italicus sexlarius, the Italian pint, was one-sixteenth of the Italicus modius, and was therefore a trifling decimal under one dry pint; it was, however, employed mainly for liquids and equaled .578 liquid quarts.

Other goods were sold by the piece, or by number; the size or quality was often specified. The pay of artisans, teachers and lawyers was reckoned by the time or by the services; and the same was true of charges for transportation and the like.

' It is regrettable that the price of wheat is lost on the record; when it is mentioned at other times in Roman bistory, it is chiefly in times of scarcity or of over-abundance. Thus in 210 B. C., during the second Punic War, wheat rose to $\$ 1.67$ per brishel (Polybius, History IX, 45.3 ), while the poet Martial, in IOI A. D., speaks of a harvest so plentiful that wheat sold at 17 cents per bushel (Martial, Epigrams, XII, 76). But the real interest in these prices is not in their absolute value, but in their relation to wages paid at that time. 
Pork

Beef

Best Bacon

Best Ham

Male Pheasant, fatted

Hens

Partridges

Hare

Peacock

Quail

Lamb

Sea fish

River fish

Oysters

Artichokes

Lettuce

Onions, fresh

Cultivated asparagus

Eggs

Apples, best

Sheep's milk

Fresh cheese

Farm laborers ${ }^{8}$

Mason, carpenter

Wall decorator

Baker

Ship worker

Barber

Teacher of reading and writing

Teacher of Greek and Latin

Teacher of public speaking

Lawyer, for getting the matter before a court

Lawyer, for services during trial

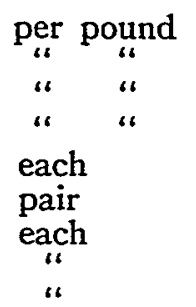

$\$ .072$

.048

.096

.117

I.085

.2604

.1302

$.65 \mathrm{I}$

"6

r.302

per pound $\quad .0718$

"، ".

". $\quad .072$

" hundred $\quad .435$

" five $\quad .0434$

" head $\quad .0174$

" twenty-five $\quad .0174$

" " " $\quad .026$

" dozen $\quad .052 \mathrm{I}$

" ten .0174

“quart $\quad .06$

" quart

"day .

"“ "

" " 65

" " $\quad .217$

“" 10.26

“ man $\quad .087$

“" pupil monthly .217

" " " .808

“ " " 1.08

" case $\quad 1.08$

" 4.34

Ox hide, tanned

Beaver's skin, tanned

Leopard's skin, tanned

Seal skin, tanned

Country worker's shoes

Patrician's shoes

Woman's shoes

Fir or Pine beams, 2000 board feet

Transportation, one person, one mile Wagon load of $866 \mathrm{lbs}$.

Camel load of 433 lbs.

B Many of these workers seem poorly paid in relation to the price of food, but we should note that most of them are furnished with their meals by the employer. 
Raw silk ${ }^{9}$

Washed Wool, fine

$$
\begin{array}{cc}
\text { per pound } & 72.18 \\
\text { " } & \text { I.052 }
\end{array}
$$

Washed Wool, ordinary

Roland G. Kent

University of Pennsylvania.

? The high cost of silk was due to the fact that it was brought from China by land transportation. 